\title{
Analisis Atribut Seismik Instantaneous Frequency Untuk Sebaran Reservoir Batupasir Formasi Tensleep Lapangan Teapot Dome
}

\author{
Hamriani Ryka ${ }^{1}$, Lourensius Hotmartua Nainggolan ${ }^{2}$, Kukuh Jalu Waskita $^{2}$, Ikhwannur Adha ${ }^{1 *}$ \\ ${ }^{1}$ Program Studi Teknik Geologi, Sekolah Tinggi Teknologi Minyak dan Gas Bumi Balikpapan \\ ${ }^{2}$ Program Studi Teknik Perminyakan, Sekolah Tinggi Teknologi Minyak dan Gas Bumi Balikpapan
}

\begin{abstract}
Abstrak
Lapangan Teapot Dome berada di Wyoming Tengah, Amerika Serikat. Lapangan ini tercatat sebagai 100 lapangan penghasil minyak terbesar di Amerika Serikat dengan cadangan yang terbukti sebesar 42.515.000 barrel. Lapangan ini berada dekat dengan tepi barat daya Cekungan Powder River. Bagian terdalam dari Cekungan Powder River terdiri dari hampir 5.500 meter batuan sedimen, dan sekitar 2.440 meter dari sedimen tersebut merupakan sedimen non marin yang berumur Kapur Akhir dan batuan sedimen klastik Tersier yang berhubungan dengan Orogenesis Laramide. Penelitian ini difokuskan pada bagian Pennsylvanian, khususnya pada bagian Top Sand B. Lapisan ini merupakan lapisan batupasir yang cukup tebal dengan Eolian Dunes. Pemetaan yang dilakukan ini untuk mengetahui sebaran reservoir batupasir pada Top Sand B dengan analisis atribut seismik menggunakan atribut instantaneous frequency dengan menggunakan data seismik 3D Post Stack Time Migration dengan menggunakan 3 sumur sebagai pengontrol untuk formasi dan kedalaman. Berdasarkan hasil analisis atribut seismik menunjukkan bahwa atribut instantaneous frequency dapat menggambarkan sebaran reservoir batupasir pada bagian Top Sand B dengan perubahan yang dapat dilihat berdasarkan perubahan warna dalam bentuk peta. Dengan dominasi persebaran batupasir berada di wilayah bagian selatan Lapangan Teapot Dome. Hal ini juga dipengaruhi oleh struktur patahan pada Formasi Tensleep.
\end{abstract}

Kata kunci: Atribut; instantaneous frequency; reservoir batupasir.

\begin{abstract}
Teapot Dome Field is located in Central Wyoming, United States. This field is listed as the 100 largest oil producing field in the United States with proven reserves of 42,515,000 barrels. This field is close to the southwest bank of the Powder River Basin. The deepest part of the Powder River Basin consists of nearly 5,500 meters of sedimentary rock, and about 2,440 meters of these sediments are Upper Cretaceous non-marine sediments and tertiary clastic sedimentary rocks associated with Laramide Orogenesis. This research is focused on the Pennsylvanian section, especially the Top Sand B section. This layer is a layer of Sandstone that is thick enough with Eolian Dunes. Mapping is done to determine the distribution of Sandstone reservoirs in Top Sand B with seismic attribute analysis using the instantaneous frequency attribute using $3 D$ post stack time migration seismic data using 3 wells as control for formation and depth. Based on the results of the seismic attribute analysis, it shows that the instantaneous frequency attribute can describe the distribution of the Sandstone reservoir in the Top Sand B section with changes that can be seen based on color changes in the form of a map. With the dominance of the distribution of Sandstones in the southern area of the Teapot Dome Field. This is also influenced by the fault structure in the Tensleep Formation.
\end{abstract}

Keywords: Attribute; sandstone reservoir; instantaneous frequency.

\footnotetext{
*) Korespondensi: ikhwannur.adha@gmail.com

Diajukan : 24 Juni 2021

Diterima : 14 Oktober 2021

Diterbitkan : 30 November 2021
} 


\section{PENDAHULUAN}

Seismik merupakan salah satu metode dalam eksplorasi geofisika untuk mencari sumber daya alam minyak dan gas bumi. Metode seismik memanfaatkan gelombang seismik yang hasilnya akan diproses sehingga menjadi penampang seismik. Penampang seismik dapat digunakan dalam interpretasi untuk mengetahui potensi minyak dan gas bumi pada suatu lapangan. Pembahasan akan lebih difokuskan dalam interpretasi mengenai penyebaran reservoir litologi batupasir dengan menggunakan analisis dari atribut seismik untuk langkah awal dalam pengembangan pada daerah eksplorasi minyak dan gas bumi. Penelitian ini dilakukan untuk mengetahui dan memahami dalam interpretasi untuk suatu penyebaran reservoir dengan menggunakan analisis dari atribut seismik instantaneous frequency dengan penggunaan data sumur dan penampang seismik.

\section{Geologi Regional Daerah Penelitian}

Lokasi penelitian berada di Lapangan Teapot Dome (Gambar 1), nama yang digunakan berasal dari struktur kubah yang berada di wilayah Wyoming Tengah, Amerika Serikat yang berada di dekat dengan tepi barat daya Cekungan Powder River. Bagian paling dalam dari Cekungan Powder River terdiri dari hampir 5.500 meter batuan sedimen, dan sekitar 2.440 meter dari sedimen tersebut merupakan sedimen non marin yang berumur Kapur Akhir dan batuan sedimen klastik Tersier yang berhubungan dengan Orogenesis Laramide (Pramada, 2008). Cekungan Powder River mengalami pengangkatan akibat dari Laramide Uplifts secara bervariasi pada beberapa bagian cekungan. Bagian yang mengalami deformasi terbesar terjadi di tepi sepanjang bagian barat dan utara, dengan ini maka Kubah Teapot menjadi salah satu struktur yang berperan menjadi perangkap hidrokarbon yang produktif dengan berasosiasi terhadap struktur Laramide Uplifts.

\section{Atribut Seismik Instantaneous Frequency}

Atribut seismik merupakan pengolahan data yang cukup baik untuk menggambarkan citra seismik yang lebih baik dan pengukuran zonazona yang menarik serta untuk menentukan struktur atau lingkungan pengendapan (Chopra dan Marfurt, 2005). Pemilihan jenis atribut seismik instantaneous frequency ini didasarkan pada kebutuhan interpretasi seismik, dimana untuk atribut seismik ini dapat membantu dalam analisis pembahasan di penelitian ini. Instantaneous frequency digambarkan sebagai laju perubahan waktu dari fase sesaat atas window yang ditetapkan pengguna (Gambar 2).

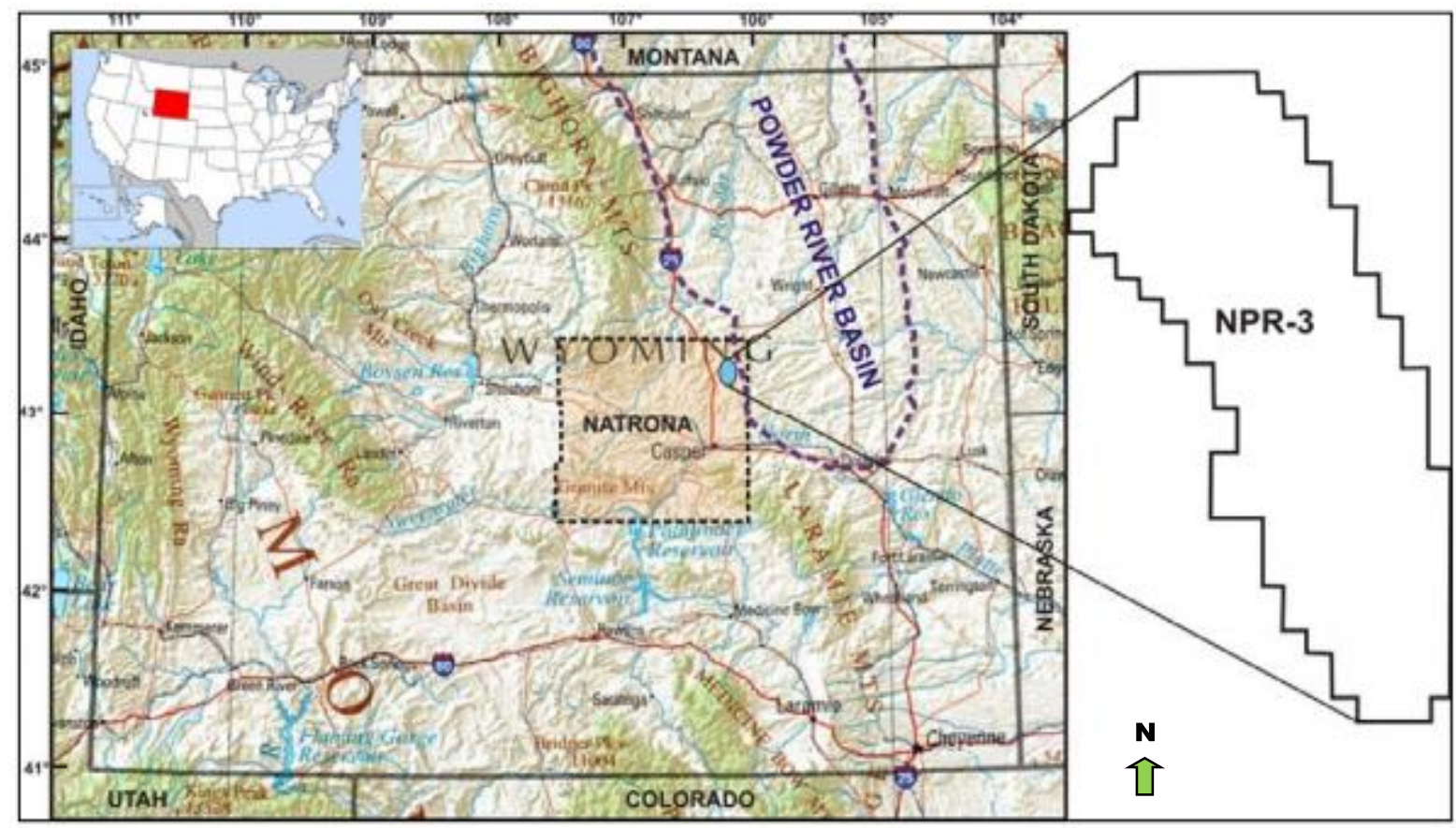

Gambar 1. Lokasi Penelitian Teapot Dome, Wyoming, USA (Pramada, 2008) 
Instantaneous frequency adalah atribut independen amplitudo dan fase informasi dan mewakili frekuensi terpusat seketika, atau frekuensi spektrum frekuensi berarti (Taner dkk., 1979). Nilai negatif dari instantaneous frequency terkait dengan fase pembalikan sudut, yang secara otomatis diubah menjadi nilai nol, dengan algoritma yang menghitung atribut ini di Petrel 2.008,1 (Schlumberger, 2007). Instantaneous frequency digunakan juga untuk melihat zona rekahan karena zona rekahan akan berasosiasi dengan zona frekuensi rendah. Selain itu dapat digunakan sebagai indikator ketebalan lapisan serta untuk melihat geometri perlapisan yang masif seperti sand-prone lithologies.

\section{METODOLOGI}

Pada penelitian ini daerah yang akan difokuskan hanya pada reservoir batupasir pada Formasi Tensleep Lapangan Teapot Dome. Adapun data yang digunakan pada penelitian ini (Gambar 3) diantaranya adalah data:

1. Data seismik 3D post stack time migration dengan inline berjumlah 345 pada cross line 188 dan pada sampling rate sebesar $2 \mathrm{~ms}$. Data ini merupakan data open source dan merupakan hak milik dari Society of Exploration Geophysicists (SEG).
2. Data sumur yang digunakan pada penelitian ini menggunakan 3 data sumur, yang akan digunakan dalam melakukan analisis sebaran reservoir serta penetuan zona target berdasarkan data log gamma ray, resistivitas, densitas, dan Neutron.

\section{Analisis Petrofisika}

Terdapat dua jenis analisis petrofisika, yaitu analisis kualitatif dan analisis kuantitatif, namun pada penelitian ini hanya menggunakan analisis secara kualitatif. Analisis kualitatif dilakukan dengan analisis data logging untuk penentuan litologi batuan. Penentuan litologi dilakukan dengan melihat kurva dari log gamma ray untuk menentukan perbedaan lapisan serpih dan bukan serpih serta dapat didukung dengan log densitas dan neutron yang dapat membentuk kurva log yang saling berpotongan membentuk cross over, karena menjadi indikasi awal adanya porositas di lapisan batuan bukan serpih. Pada penelitian ini analisis dilakukan secara quicklook dengan melihat log gamma ray, resistivitas, dan densitas neutron yang dapat memberikan informasi mengenai zona prospek hidrokarbon dengan menganalisis kurva dari masing-masing log tersebut.

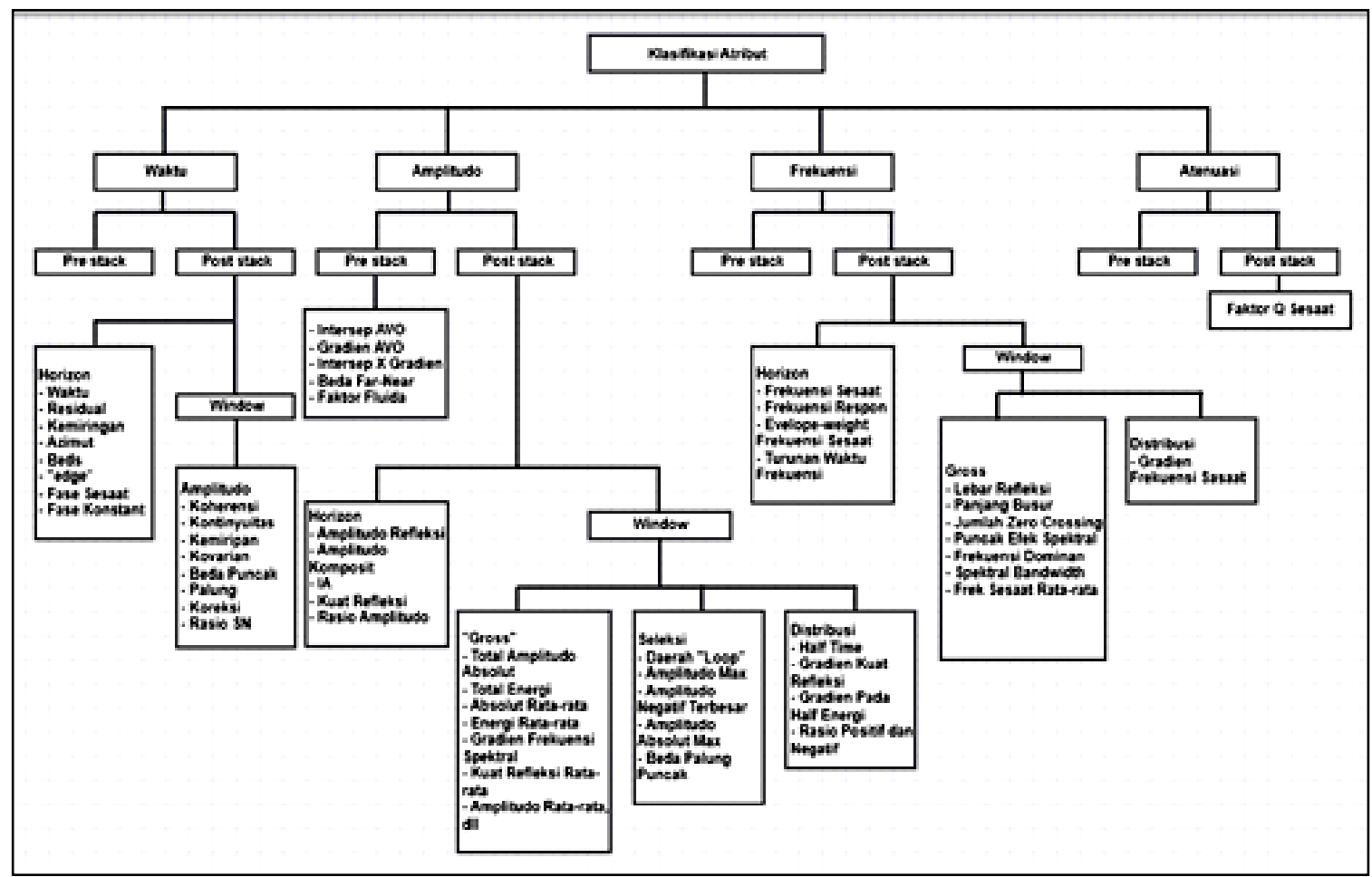

Gambar 2. Klasifikasi atribut seismik (Brown, 2011). 


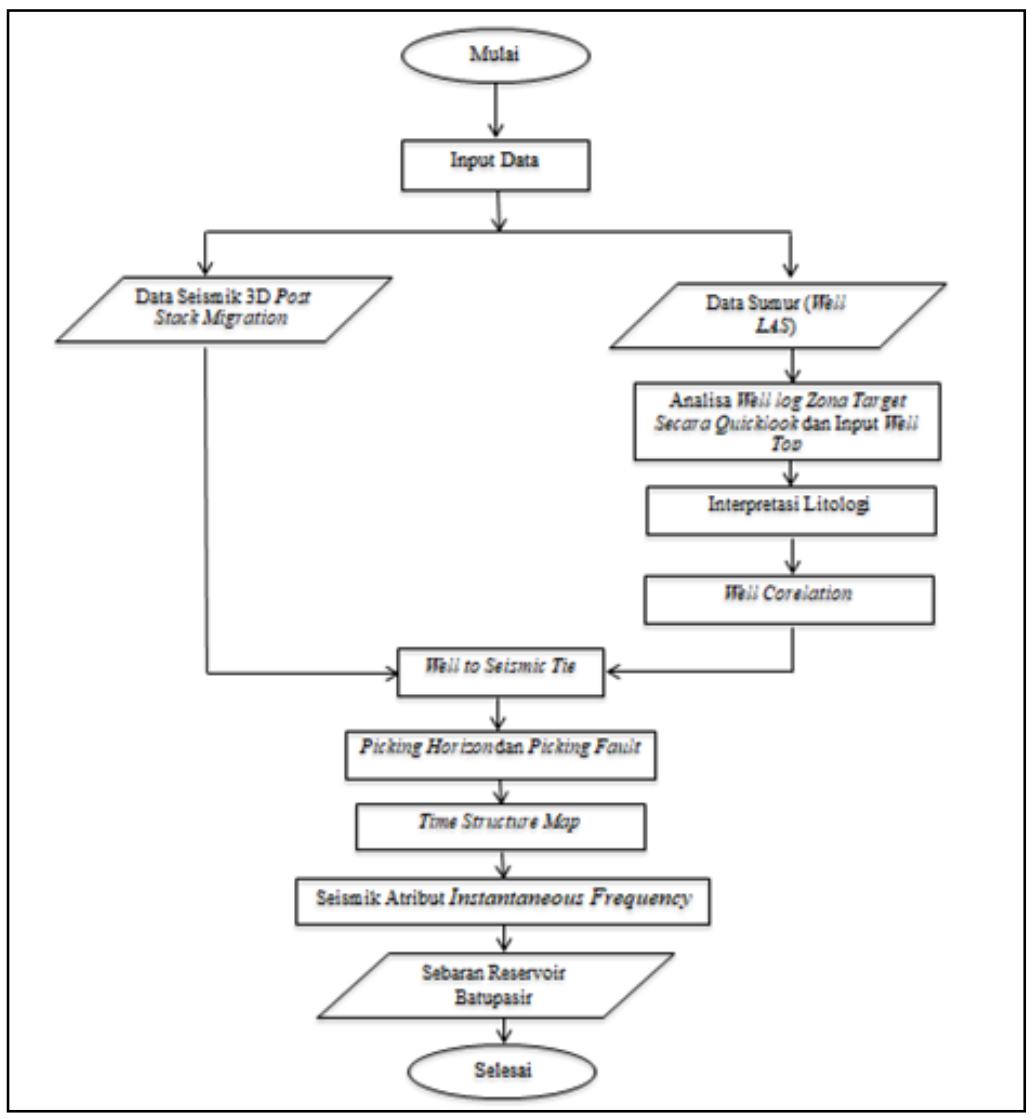

Gambar 3. Bagan Alir Penelitian

\section{Well Seismic Tie}

Proses analisis diawali dengan pengikatan antara data sumur dan data seismik, yang dilakukan pada data sumur yang masih memiliki domain kedalaman (depth). Data sumur yang digunakan memiliki satuan kaki (ft), sedangkan data seismik masih dalam domain waktu dengan satuan milidetik (ms). Pengikatan ini dilakukan untuk menyamakan domain antara data sumur dan data seismik dalam domain waktu, sehingga horizon pada data seismik dapat berada di kedalaman yang tepat atau sebenarnya seperti pada data sumur. Pada proses pengikatan ini ada beberapa log yang harus ada pada data sumur, diantaranya adalah log sonik (DT) dan densitas (RHOB) serta data checkshot. Selanjutnya membuat koefisien refleksi (RC) dari perbandingan nilai accoustic impedance yang merupakan dari perkalian log DT dan log RHOB. RC ini kemudian dikonvolusikan dengan wavelet yang telah diekstrak untuk menghasilkan sintetik seismogram.

\section{Picking Horizon dan Picking Fault}

Picking Horizon dilakukan untuk memperlihatkan gambaran zona target yang diidentifikasi sebagai lapisan zona reservoir secara lateral dengan kenampakan dari data seismiknya. Picking horizon ini dapat dilakukan baik secara 2D maupun 3D. Pada penelitian ini picking horizon yang dilakukan pada Top Horizon Sandstone B pada seluruh inline dan crossline dengan jarak spasi per 16. Picking fault dilakukan dengan penarikan garis yang dianggap sesar pada daerah penelitian. Picking fault ini dilakukan setelah melakukan picking horizon agar dapat menentukan kemenerusan patahan serta arah dari patahan tersebut.

\section{HASIL}

Penentuan litologi dilakukan dengan menggunakan analisis data logging secara kualitatif dengan mengunakan log Gamma Ray yang tersedia pada setiap sumur yang akan mempresentasikan defleksi kurva batupasir. Berdasarkan Gambar 4, dari tiga sumur yang digunakan sebagai data awal dalam analisis yang dilakukan untuk penentuan litologi pada Formasi Tensleep, zona yang menjadi target merupakan lapisan batu pasir pada Sandstone B dengan tebal 60-65 ft yang merata pada data log sumur yang digunakan. 


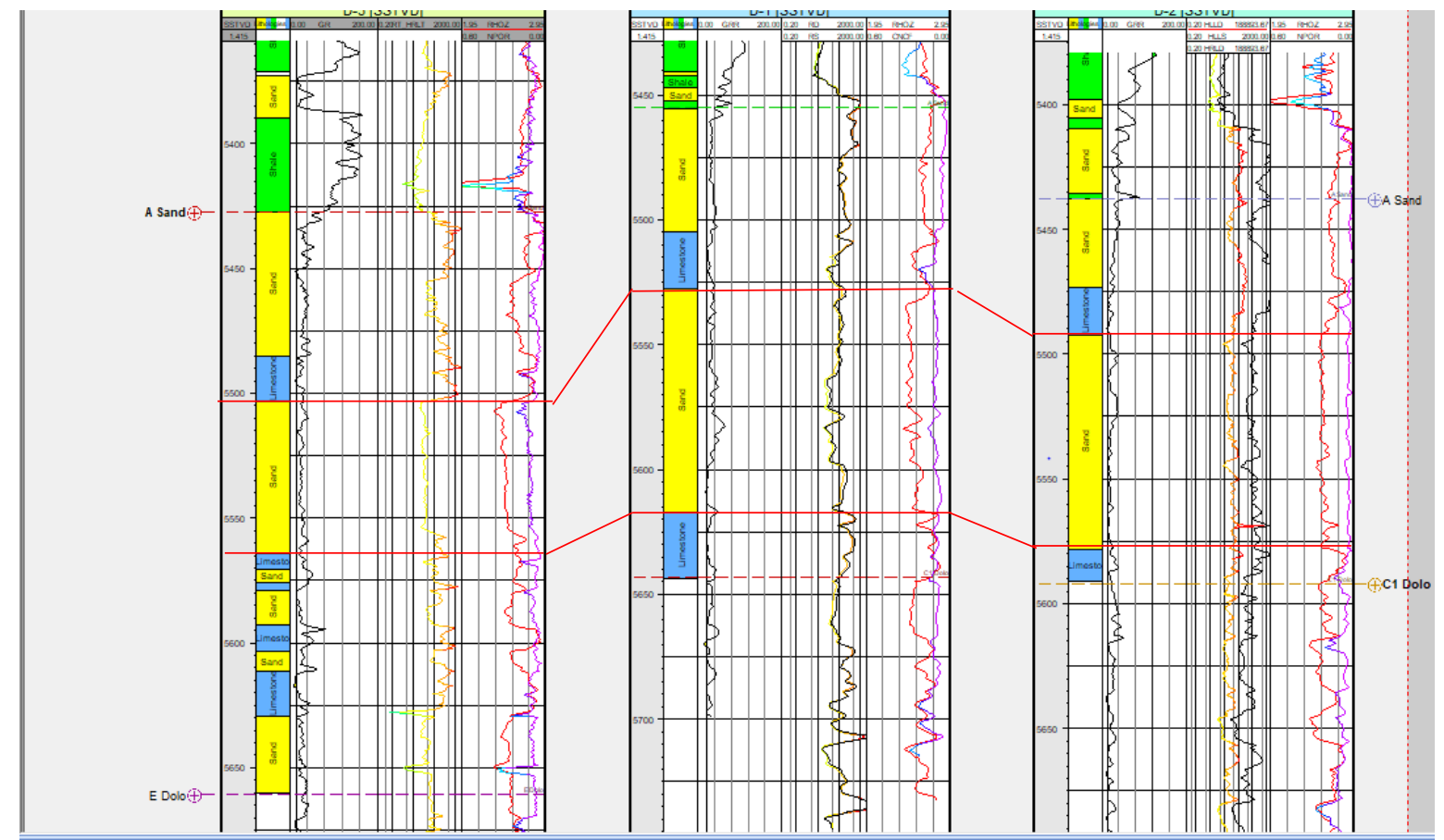

Gambar 4. Zona target yang dibatasi oleh garis merah.

Interpretasi Horizon dan Interpretasi Sesar pada Data Seismik

Interpretasi bertujuan untuk mengetahui penyebaran litologi reservoir secara lateral dan menganalisis serta menentukan struktur yang ada pada data seismik daerah penelitian. Berdasarkan hasil interpretasi akan didapatkan gambaran struktur bawah permukaan dalam bentuk penampang peta struktur waktu (Time Structure Map). Picking horizon yang dilakukan pada penelitian ini hanya difokuskan pada Formasi Tensleep lapisan Sandstone B dengan ketebalan $61 \mathrm{ft}$ dan pada Top Sandstone B saja. Berdasarkan Gambar 5, hasil analisis interpretasi picking horizon yang dilakukan, pada setiap horison pada data seismik dapat dilakukan penarikan horison secara lateral secara menyeluruh. Dalam penelitian ini terdapat tiga patahan yang dapat di interpretasikan dan dianalisis, namun tidak semua bersinggungan langsung dengan penarikan horison yang dilakukan, namun tetap berkaitan dengan horison pada lapisan Sandstone B.

Struktur patahan yang terdapat pada daerah penelitian merupakan struktur patahan yang berarah barat daya-timur (Gambar 6A), yang dapat didukung dengan geologi regional daerah penelitian yaitu struktur patahan pada Formasi Tensleep dengan arah Barat daya-Timur laut.
Struktur patahan yang kedua (Gambar 6B) merupakan patahan yang juga berarah Barat daya-Timur laut yang berdekatan dengan struktur ketiga. Struktur patahan yang ketiga (Gambar 6C) merupakan struktur patahan yang juga berarah Barat daya-Timur laut.

\section{PEMBAHASAN}

Berdasarkan interpretasi seismik yang dilakukan didapatkan peta struktur waktu untuk top horison dari Formasi Tensleep dengan lapisan target adalah Sandstone B berdasarkan sumur D1. Horison menyebar atau melampar cukup luas. Peta struktur waktu yang telah diekstraksi menggunakan atribut instantaneous frequency mendapatkan hasil dari picking horizon pada tiap lapisan Sandstone B yang melintasi data seismic (Gambar 7), sehingga dari atribut instantaneous frequency dapat mengetahui sebaran dari reservoir batupasir pada Formasi Tensleep secara lateral. Persebaran reservoir batupasir pada Formasi Tensleep yang memiliki warna biru muda sampai dengan biru tua, dimana ini menunjukkan nilai frekuensi yang rendah sehingga dapat dilihat pola persebaran zona reservoir batupasir dominan berada pada bagian Selatan Lapangan Teapot Dome. 

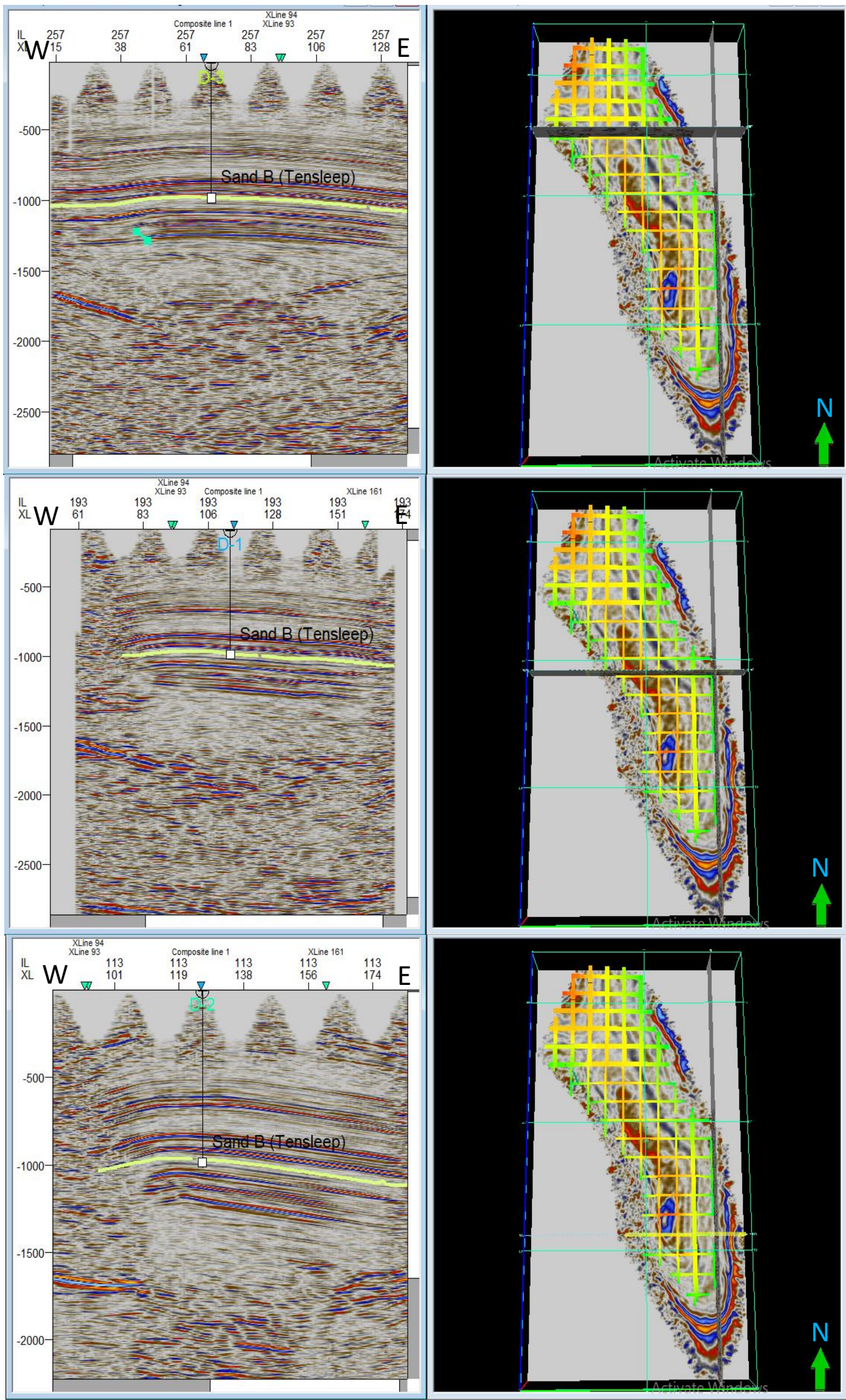

Gambar 5. Picking horizon pada data seismik. 

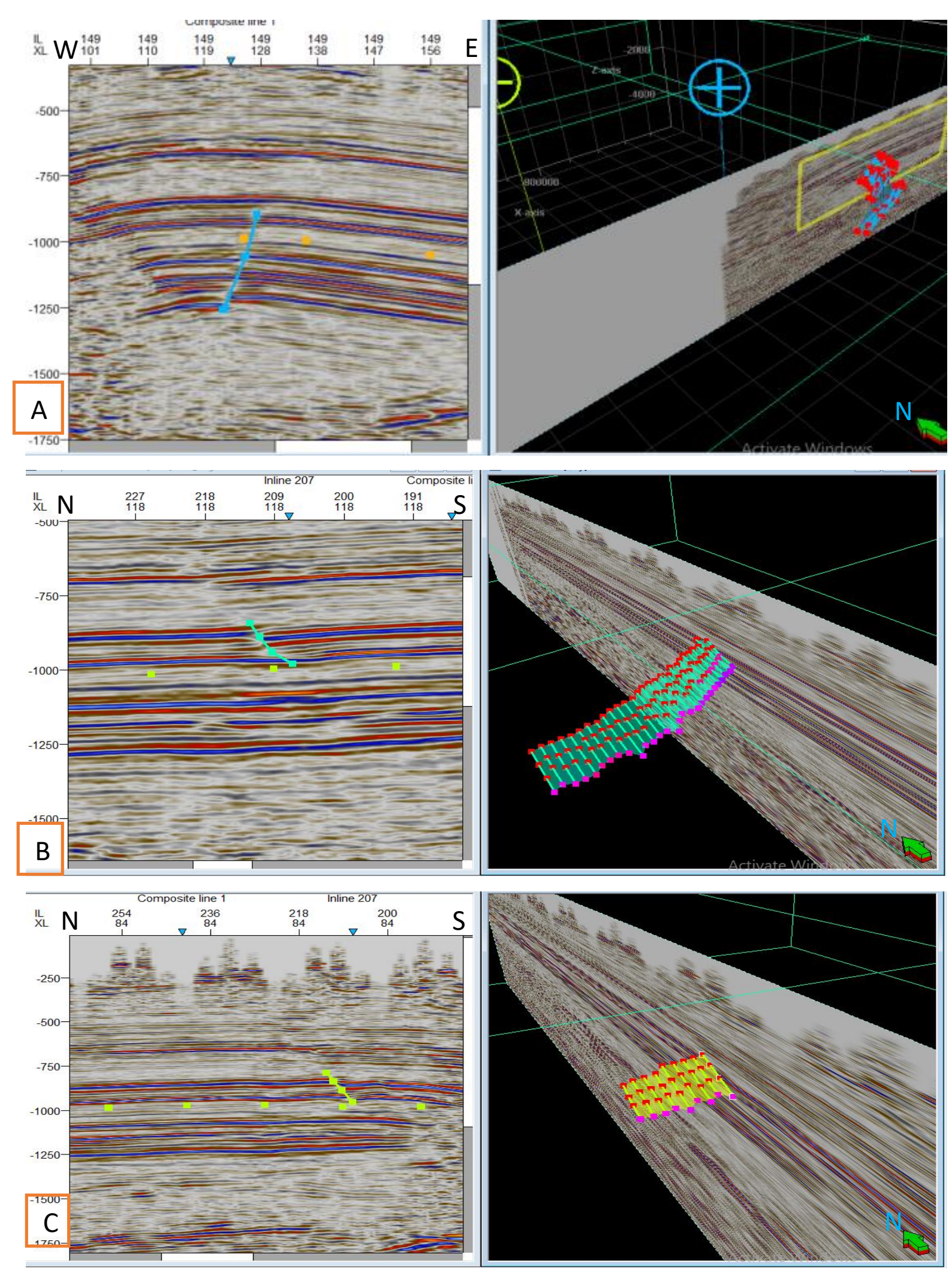

Gambar 6. Picking Fault pada data seismik (Reverse Fault). 


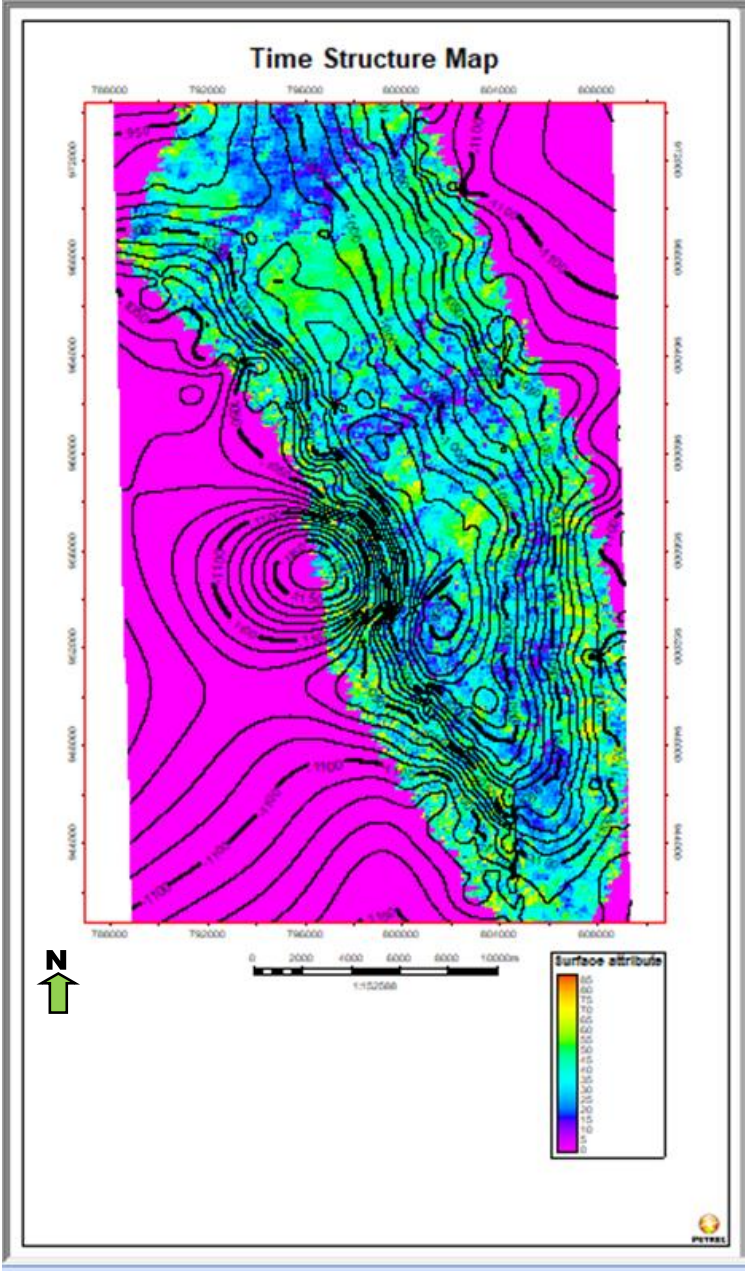

Gambar 7. Peta struktur waktu lapisan Sandstone B dengan atribut instantaneous frequency.

\section{KESIMPULAN}

Berdasarkan dari data log sumur diketahui bahwa defleksi dari log gamma ray memiliki nilai relatif rendah pada Formasi Tensleep terutama pada zona Sandstone B yang menjadi reservoir dengan litologi batupasir. Berdasarkan hasil dari analisis menggunakan atribut seismik instantaneous frequency diketahui pola penyebaran reservoir batupasir secara lateral berada pada bagian Selatan dari Lapangan Teapot Dome.

\section{UCAPAN TERIMA KASIH}

Penulis berterima kasih kepada seluruh anggota Tim Sekolah Tinggi Teknologi Minyak dan Gas Bumi Balikpapan yang telah membantu dalam pengambilan data dan analisis, serta semua pihak yang telah memberikan saran sehingga menjadikan tulisan ini lebih baik.

\section{DAFTAR PUSTAKA}

Brown, A.R., 2011. Interpretation of ThreeDimensional Seismic Data. Interpretation of Three-Dimensional Seismic Data, Society of Exploration Geophysicists and American Association of Petroleum Geologists, hal.617-646.

Chopra, S. dan Marfurt, K.J., 2005. Seismic attributes - a historical perspective. Geophysics, 70, 3SO-28SO.

Pramada, S., 2008. Peningkatan resolusi gambar patahan dengan teknik tracking (ant-track) pada seismik $3 D$ dan aplikasinya untuk analisis struktur pada reservoir rekahan. Universitas Indonesia, Jakarta.

Schlumberger, 2007. Interpreter's Guide to Seismic Attributes. Hal 115.

Taner, M.T.K., Koehler, F., Sheriff, R.F., 1979. Complex seismic trace analysis. Geophysics, 44, hal 1041-1063. 